\title{
Características sociourbanas de la Lima de Ricardo Palma
}

Por Eduardo Arroyo Laguna 
Sociólogo, poeta, narrador, promotor cultural y periodista. Doctor en Ciencia Política y Relaciones Internacionales, directivo del Colegio de Sociólogos del Perú y de la Asociación Amigos de Mariátegui. Miembro de la Comunidad Nacional por el Centenario de José María Arguedas. 
El patriarca de los escritores peruanos, don Ricardo Palma Soriano, nació el 7 de febrero de 1833 y falleció el 6 de octubre de 1919, es decir, hace noventa y cinco años.

En las circunstancias de espacio y tiempo en las que le tocó vivir, demostró estar a la altura de los exigencias epocales superando en mucho las constricciones propias de vivir en una Lima amurallada, casi una aldea feudal, con un trasfondo aristocrático colonial en la vida y acciones de la población de entonces. Antepuso una actitud militante ante la existencia y, a la vez, una gran versación sobre los temas que trató con suma versatilidad y entrega a la literatura.

La historia recuerda al Palma contador público, marino de guerra, periodista, poeta, dramaturgo, ensayista, novelista, inventor del género de las tradiciones literarias, luchador por diversas causas políticas, exiliado.

Peleó por lo que consideró justo sufriendo el destierro. Fue un romántico que no miró la vida desde un cómodo balcón sino desde el lado protagónico de la misma.

Cultivó de paso todos los géneros literarios: poesía -desde su adolescencia- hasta novela, drama, sátira, crítica, crónica periodística y ensayos. Ya a los 15 años hacía poesía y había escrito un drama. Muy joven lo vemos secundando la sublevación de Manuel Ignacio de Vivanco contra Ramón Castilla. 
Masón a los 22 años, participó en su vida marina en diversos barcos de guerra, goletas, bergantines, barcos mercantes y vapores. Hacia 1860, la historia lo recuerda asaltando la casa presidencial de Ramón Castilla, exiliándose luego en Chile. Allí se relacionó con los principales escritores del vecino país del sur. Amnistiado, regresó al Perú en 1863 y fue nombrado Cónsul en Pará, Brasil, cargo que no desempeñó porque viajó a Europa y retornó vía New York, llegando al Callao bloqueado por las flotas españolas, asistiendo a Gálvez, ministro de Guerra y Marina, participando ambos, desde la torre La Merced del Callao, en el combate contra la escuadra española el 2 de mayo de 1866. Gálvez fallece y Palma se salva. También participó de la sublevación dirigida por el coronel José Balta, siendo deportado a Guayaquil. Al volver, pasó a ser secretario de Balta, tras ser elegido este como presidente en 1868. La trágica muerte del mandatario en 1872 marca también el fin de la vida política de Palma, quien se retira a Miraflores y en 1878 se muda con su familia a Chorrillos.

$\mathrm{Al}$ poco tiempo, la guerra con Chile lo lleva a defender Lima. Su casa de Miraflores es incendiada quemándose su amplia biblioteca y bibliografía por publicar.

Será tras la guerra que acepta dirigir la Biblioteca Nacional del Perú, inaugurándola el 28 de julio de 1884 y dirigiéndola hasta febrero de 1912. Ya en marzo de 1912 se retira a sus cuarteles de invierno, en Miraflores.

Vivió entre 1833 y 1919, es decir, le tocó vivir años postindependentistas hasta los inicios del Oncenio de Leguía.

Palma padre, casado con doña Cristina Román Olivier, Palma guerrero, Palma literato, Palma versador de la Lima antigua y de su tiempo, muere el 6 de octubre de 1919 y como todo ser humano no pudo escapar, como nadie podría, de las circunstancias de espacio y tiempo que le tocó vivir. 


\section{Circunstancias de espacio y tiempo de Ricardo Palma}

El tradicionista tiene un amplio conocimiento del mundo, de sus países, como de la historia del Perú, la que adereza con sus sabrosos escritos.

Por su obra desfilan todas las épocas del Perú y sus regiones. Está informado e interesado por lo que ocurre en el territorio nacional. Para ello, considerando las dificultades de la época y lo pequeña que era la Lima en que le toca vivir, no necesariamente tiene que haber viajado a cada lugar sino que se cartea con peruanos de diferentes departamentos y provincias y mantiene viva la llama de la amistad, el hermanamiento con todos los connacionales, así como lo hará con todos los habitantes del mundo.

Ama a Lima. Es un romántico pero paradójicamente es también un liberal, como lo atestiguan sus posiciones anticlericales y radicales.

Conoce Lima, esa aldehuela que era la Lima de su infancia en el primer cuarto del siglo XIX. Esa y las Limas de épocas anteriores serán las que el tradicionista recordará, la Lima física así como la Lima multicultural que le toca presenciar transmitiéndonos también su propia ciudad interior. Nos referimos a la Lima personal de Palma, aquella que el autor crea y recrea.

Al respecto, Italo Calvino nos dice que “...La ciudad no está hecha de esto, sino de relaciones entre las medidas de su espacio y los acontecimientos de su pasado... En esta ola de recuerdos que refluye la ciudad se embebe como una esponja y se dilata. Una descripción de Zaira tal como es hoy debería contener todo el pasado de Zaira. Pero la ciudad no dice su pasado, lo contiene como las líneas de una mano, escrito en las esquinas de las calles, en las rejas de las ventanas, en los pasamanos de 
las escaleras, en las antenas de los pararrayos, en las astas de las banderas, cada segmento surcado a su vez por arañazos, muescas, incisiones, comas." 1

Cada ciudad contiene, resume y evoca su utopía de origen, su pasado, su presente y su futuro. En cada espacio de la urbe está escrita su historia. En cada una de ellas viven sus elementos constitutivos, las ideas que la originaron, la memoria de lo que fue, lo que es y lo que será. Pero, a su vez, cada ciudadano armará y amará su propia ciudad espiritual, interna, cuyas vivencias atesorará y vivirá profundamente.

Don Ricardo Palma es hijo de un tiempo y espacio. Es tributario de un país y su historia. Hereda sus alegrías así como sus frustraciones colectivas y nos deja como enseñanza su visión del Perú, y centralmente, de Lima.

Pedro Díaz Ortiz refiere que ninguno como Palma ha retratado mejor sus personajes, calles, plazas y conventos y citando a "Mogollón (1747). Origen del nombre de esta calle" nos dice que "...haciendo guerra sin cuartel a los recuerdos poéticos de un pueblo que en cada piedra y cada nombre esconde una historia, un drama, una tradición"... ${ }^{2}$, cita un trabajo sobre la ciudad de Granada en la literatura donde plantea que “... Los escritores tienen sus ciudades, como los artistas tienen sus musas; en ellas se inspiran y en ellas imaginan y recrean su historia y sus personajes, sus mitos y sus mundos posibles. Los escritores modelan sus sueños en las ciudades, proyectan sus anhelos en ellas y ocupan así sus barrios, sus calles, sus

I Calvino Ítalo, "Las ciudades invisibles", Colección Millenium, publicada por EL MUNDO, Unidad Editorial, S.A., Madrid 1999, página 22. Traducción cedida por Ediciones Siruela, S.A. Traducción de Aurora Bernárdez.

2 Ricardo Palma, "Tradiciones Peruanas completas", edición y prólogo de Edith Palma, nieta del autor con siete extensos apéndices y una selección de cartas del autor, ediciones Aguilar, Madrid 1964, quinta edición, página 579. 
mercados y sus plazas, su atmósfera, hasta el punto de sentirse cautivos, de hacernos sentir cautivos de una cierta fascinación literaria"3.

La Lima que Palma recorre es una Lima pequeña en donde uno podía ser amigo de mucha gente con solo recorrerla en pocos trancos. La ciudad inspira y los literatos se apoderan de ella, caen seducidos por sus encantos, sus misterios, su llamado, las anécdotas que encierran en sus esquinas. El tradicionista, en muchos casos, presenta a los personajes de su obra y, acto inmediato, los sitúa en el espacio urbano de la capital peruana, sean calles, jirones, iglesias, etc. Además, la predilección de Palma lo llevará a nunca arrodillarse ante ningún personaje de la Colonia, español o española, sino a preferir a miembros del pueblo limeño mestizo. Lima y sus personajes motivan la obra palmista.

Palma vivió entre 1833 y 1919. Ese fue su tiempo como un hijo aprovechado. Y como diría Ortega y Gasset, uno es uno y sus circunstancias. Indudablemente que el humor epocal influye en cualquier persona. En Palma lo hizo como lo hicieron las circunstancias de espacio y tiempo que le tocó vivir. La sociedad en la que se nace, la época, los propios talentos que uno trae y las decisiones que uno toma en la vida forman parte importante de la biografía de toda persona.

Nos dice Edith Palma, nieta del escritor, que el tradicionista nace nueve años después de la batalla de Ayacucho, que consolida la libertad del Perú y de América. Refiere Angélica Palma, su hija predilecta, que “...Aquellos comienzos del año 1833, en que el Perú vio nacer en su capital poética

3 Díaz Ortiz Pedro, http: www. ciceronegranada.com/9e_literatura.shtml. Tomado del artículo "Lima y Ricardo Palma” de Pedro Díaz, en Revista Aula Palma, Instituto Ricardo Palma, Universidad Ricardo Palma, año de 2008, página 83. 
al más representativo de sus literatos, hijo señero de Lima, fueron para la incipiente República de peligrosa turbulencia política, que continuaría, durante corto período, en fatal progresión" 4 .

Nos sigue diciendo Edith Palma que su abuelo heredó, sin duda alguna, las virtudes heroicas de su tiempo y que será Raúl Porras Barrenechea, el historiador de Lima y del Perú quien trace el cuadro preciso de la infancia de don Ricardo Palma, al decir:

"Palma abrió los ojos en el corazón de la Lima virreinal. Por la espalda, los muros de su casa tocaban con los de las cárceles de la Inquisición limeña, cuya historia sería el primero en escribir. A media cuadra de su hogar, en lo que es hoy Plaza Bolívar, funcionaba el mercado o plaza de abastos y el desplante dicharachero de las mulatas vendedoras de pescado y desenvoltura. Pocos pasos más allá, en el sitio que ocupa actualmente el Congreso, estaba el edificio de la Universidad Nacional Mayor de San Marcos, con sus muros altos y severos, su claustro imponente, en el que se alineaban los retratos de frailes catedráticos e inquisidores, y en cuyo General funcionaba, desde 1822, el Congreso. En un ángulo de la manzana en que vivía Palma, estaba la casa en cuya entrada la tradición popular asegura que había fallecido el virrey Conde de Nieva al descender de un balcón. El otro ángulo daba frente al monasterio de la Concepción, fundado por una cuñada del conquistador Pizarro. Cuadra debajo de la Concepción estaba el Colegio del Príncipe, fundado por el virrey Esquilache y dedicado ya a la Biblioteca Nacional. Son casi todos los lugares entre los

4 Edith Palma, Prólogo de Las Tradiciones Peruanas Completas titulado "Ricardo Palma y sus Tradiciones Peruanas", "Breve biografía de Ricardo Palma”, Ediciones Aguilar, Madrid 1964, quinta edición, página XVIII. 
que había de transcurrir la vida del tradicionista", nos dice Raúl Porras Barrenechea ${ }^{5}$.

Palma, nacido en una familia que pasaba por penurias económicas, pobló su fantasiosa imaginería con los datos de su entorno. Era indudablemente una circunstancia de leyenda nacer rodeado de estas sedes institucionales. Estos espacios lo acompañarán a lo largo de su vida y emergen en cada tradición. Son sedes de instituciones importantes que lo han rodeado desde su nacimiento (Congreso, Inquisición, mercado, Universidad, monasterio de La Concepción, Colegio del Príncipe, Biblioteca Nacional). De un lado, la voz popular, dicharachera del gentío, capaz de ganar con sus dimes y diretes cualquier situación. Esta veta infantil aparecerá en algunas tradiciones, así como aparecen tradiciones en que la Inquisición descolla, o los amplios monasterios religiosos, el mundo de las plazas, calles, jirones, la pescadería, el mercado ambulatorio, el cuchicheo de las beatas y chismosas a la vez, de las tapadas, imágenes de una Lima aldehuela, pequeña, que se tragaba a ella misma con sus habladurías como, a su vez, una serie de relatos de penas y aparecidos, de fantasmas que pululan en toda pequeña ciudad y moldean su alma ciudadana.

Su infancia transcurrió, pues, en una suerte de Lima sin virreyes pero profundamente virreinal. Nada había cambiado de fondo, de esencia. Las cárceles de la Inquisición, el mercado callejero, el Congreso de la República son espacios que ha recorrido de niño de la mano de su madre o sus hermanos así como es parte de su experiencia vivir cerca al balcón desde el que un virrey enamorado cayó y pasó a mejor vida. El tradicionista nace en plena avenida Abancay, zona hoy muy transitada que en el primer cuarto del siglo XIX, como ahora, fue parte de la Lima cuadrada, a escasas cuadras de la Plaza de Armas.

5 Edith Palma, ob. ant. cit., páginas XVIII-XIX 
Palma sintetiza el trasfondo colonial que aún vivía en la mente de los limeños de aquel entonces, del siguiente modo: "No con el último disparo de fusil en el campo de Ayacucho desapareció la vida colonial. En punto a costumbres se siguió, en toda casa de buen gobierno, almorzando de nueve a diez de la mañana, comiendo de tres a cuatro de la tarde, cenando a las diez de la noche, rezando el rosario en familia antes de meterse entre palomares (vulgo: sábanas), y lo que vale por mil tesoros: se siguió ignorando que la dispepsia y los cólicos hepáticos con sus arenillas están reñidos con la antigua cocina española, en que la manteca entraba por poco y por mucho el aceite de olivo. Desafío al más guapo a que consuma hoy el par de huevos, fritos en aceite de Moquegua, que embaulaba yo dentro del cuerpo antes de ir a la escuela... El mobiliario en las casas, la indumentaria personal, las fiestas y procesiones religiosas... Las corridas de toros, el reñidero de gallos y las funciones teatrales, los saraos de buen tono, los jolgorios populacheros, todo, todo subsistía, sin ápice de discrepancia como en los días de la colonia. Nada había cambiado. Solo falta el virrey, y créanme ustedes, que la mayoría del vecindario limeño lo echaba de menos"6.

Debemos considerar, además, que Palma vive en los años de la anarquía militar, la que será otra influencia importante en su niñez y juventud. Mucha de su aventura periodística como política, la hizo en ese contexto en donde no solo participó de diversas asonadas sino que vivió en una Lima temerosa que pendulaba entre la pereza y el amotinamiento, los cierra puertas y las montoneras. Esa fue la Lima azarosa que le tocó vivir: la independencia en sus primeros años, el desorden político ante la falta de una clase burguesa que lanzara un proyecto nacional de desarrollo y encabezara la edificación capitalista del país.

6 Ricardo Palma, "El Baile de La Victoria" (1853). En "Tradiciones Peruanas Completas”, ob. ant. cit., páginas 1124-1125. 
Luis Alberto Sánchez retrata esos años del siguiente modo: "Nació Palma, como he dicho ya, en los años inmediatamente posteriores a la gesta libertadora: nueve años después de Ayacucho...Los recuerdos del niño Palma identificaron a Lima con la caída de los santacrucinos. La ciudad era aún triste y pobre...Se vivió en constante sobresalto. Los días transcurrían monótonos como en aldea dormida...Primaban los militares, engreídos por sus triunfos de la campaña emancipadora...La policía temía los asaltos de los bandidos, porque la miseria y la agitación habían favorecido la formación de montoneras. En los alrededores de la ciudad merodeaban bandas de forajidos...No se contentaban los bandoleros con su reinado en La Tablada de Lurín y Piedras Gordas...Ir a Chorrillos era ya una empresa grave...Lima está loca de revueltas, reina el caos..."7.

\section{La Lima anterior a don Ricardo Palma}

La Lima en la que nace Palma era una aldehuela de unos 65,000 pobladores. La capital peruana había heredado la traza colonial, aquella planteada por las Leyes de Indias para fundar ciudades, las que pedían un terreno plano de buen clima, fertilidad comprobada, mucha leña, agua. Pedro Cieza de León sostuvo que el valle del Rímac era el valle más hermoso de cuantos había visto allá por $1532^{8}$. Y Cieza de León no era cualquier viajero por cuanto había recorrido todos los grandes valles del mundo.

Tras haber asentado provisionalmente la capital en Jauja, Pizarro la traslada al valle del Rímac. Cobo nos dice que "En

7 Luis Alberto Sánchez, "La Lima en que vivió Palma”, En "Pequeña antología de Lima”, de Raúl Porras Barrenechea, 1535-1935. Madrid 1935. Imprenta de Galo Sáez, Mesón de Paños, 6. Madrid, páginas 316-321.

8 Pedro Cieza de León, "La Crónica del Perú", Biblioteca Peruana, Ediciones PEISA, Lima-Perú, 1973, cap. LXXI, páginas 176-177 
el pueblo de Pachacamac, a 13 días del mes de Enero de 1535 ante el dicho Señor Gobernador parecieron juntos los dichos: Ruiz Díaz, Juan Tello y Alonso Martín de Benito...El dicho Juan Tello...le parece que el asiento para hacer el dicho pueblo que se ha de hacer, estará muy bien en el asiento de Lima; porque la comarca es muy buena, y tiene leña y tierras para sementeras y cerca puerto de la mar;..."

Siguiendo las Leyes de Indias y a la usanza greco-latina de la época, la capital peruana tuvo su origen en la Plaza Mayor. La urbanística occidental nace propiamente a partir de este espacio de eminente valor social, mientras en oriente las grandes plazas eran ceremoniales. Lima, así, perfila la imagen de una ciudad greco-latina, extravertida diferente a las ciudades musulmanas plenas de laberintos y adarves, de casas y puertas pequeñas, ciudad de muros adentro, ciudad introvertida. Lima tiene espacios públicos abiertos, en los que la colectividad conversa, discute, realiza la tertulia.

Alrededor de la plaza central se ubicaron las sedes de las principales funciones urbanas. El trazado de la Casa del Gobernador (Palacio de Gobierno), el Cabildo y la Catedral expresaron la localización espacial conjunta de las funciones de gobierno, administrativa y religiosa. La plaza simbolizó un centro de conquista, es decir, el asentamiento del poder políticomilitar y el cuartel general de operaciones de conquista. De allí el apelativo de Plaza de Armas, alrededor de la cual se dieron las principales actividades de la escasa población española de aquel entonces: la función gubernamental simbolizando la opresión de la cultura nativa conquistada (expresada en la construcción

9 Bernabé Cobo, "Historia de la fundación de Lima", páginas 59-60. Extracto contenido en "Pequeña Antología de Lima” de Raúl Porras Barrenechea, 2da edición, Lima, 1965. Instituto Raúl Porras Barrenechea, Escuela de Altos Estudios y de Investigaciones Peruanistas. Universidad Nacional Mayor de San Marcos. 
de la Casa de Pizarro sobre la casa de Taulichusco), las funciones administrativas del cabildo, las misas, el Te Deum, los paseos de recreo, algunas actividades de mercado, las corridas de toros, y otras.

No se cumplieron las Leyes de Indias que legislaban que se establecieran los solares por sorteo. También se incumplió la ley VIII que señalaba que la Iglesia no debía establecerse en la Plaza Mayor, sino en otra cercana para que entre ambas se elevaran la Casa de Gobierno y el Cabildo. Con esta trasgresión se creó la tradición de tener siempre una iglesia situada en la plaza principal ${ }^{10}$. Ciudad de amplias iglesias, casi un convento era Lima colonial y esa herencia se traslada a la naciente república, cuna de Palma. Los conventos y monasterios ocupaban la mayor área urbana, así como también las mayores haciendas, las mejores tierras y el consiguiente usufructo de la renta. En su conjunto, la vida social y espiritual de la ciudad estaba regulada por la iglesia.

La capital peruana inicia su fundación europea con 70 habitantes y acaba el coloniaje con 63,900 pobladores y 400 hectáreas ${ }^{11}$. No se consideran entre los 70 mencionados a los nativos que vivían a orillas del río Rímac, dedicados a la pesca y comercialización de camarones. Difícil imaginar hoy que hubiera tal pesca en este río, tan desolado y falto de agua en la actualidad, ya que solo tiene agua en el estiaje, cuyo caudal ha disminuido dado el descongelamiento permanente de las alturas cordilleranas de las que procede este líquido vital.

El siguiente cuadro es significativo:

10 Aurelio Miró Quesada S., "La ciudad en el Perú". En "Lima, tierra y mar". Ediciones Populares, Librería Editorial Juan Mejía Baca, Lima, diciembre de 1958, página 114.

11 ONEC, Boletín de Análisis Demográfico: "La población del área metropolitana de Lima-Callao". Julio 1975, N 15, página 13. 


\begin{tabular}{cccc}
\hline Años & Población & Extensión & Tasa anual de crecimiento \\
\hline 1535 & 70 habs. & 214.7 hás. & 1535-1570: $9.76 \%$ \\
\hline 1571 & 2,000 habs. & & $1571-1599: 7.27 \%$ \\
1599 & 14,262 habs. & 314 hás. & $1599-1614: 4.20 \%$ \\
1614 & 26,441 habs. & 316 hás. & 1614-1700: $0.40 \%$ \\
1700 & 26,441 habs. & & $1700-1755: 0.68 \%$ \\
1755 & 54,000 habs. & & $1755-1791:-0.07 \%$ \\
1791 & 52,624 habs. & & $1791-1812: 0.93 \%$ \\
1812 & 63,900 habs. & 400 hás. & $1812-1820: 0.02 \%$ \\
\hline
\end{tabular}

Un puente separaría la Lima aristocrática de la plebeya, la zona alta o encima del puente, la Lima cuadrada y la Lima de abajo el puente, de indios camaroneros. La segregación sociourbana se había echado a andar. Taulichusco, gran cacique de Lima y controlador de las fuentes de agua, no sobrevivió mucho tras la invasión de estos predios y los caciques posteriores dejaron de denominarse caciques de Lima y pasaron a denominarse caciques de la Magdalena, desapareciendo casi por completo en unas décadas.

Para protegerse de los ataques piratas y quizá también para controlar a la población de esclavos que la servían, Lima fue amurallada en 1685 por el virrey Duque de la Palata, murallas que encerraron cerca de 354 hectáreas y menos de 54,000 habitantes, como también áreas de cultivo. Palma hereda esta ciudad.

Pese a las murallas y las puertas, no sería del todo lícito hablar de una nítida diferenciación entre la ciudad y el campo ya que la vida urbana se confundía con las actividades agropecuarias de los valles próximos ${ }^{12}$.

12 Alberto Flores Galindo, “Aristocracia y plebe: Lima 1760-1830”. Mosca Azul editores, I a edición, Lima, 1984, página 17. 
En Lima residió la elite virreinal más numerosa e importante de América del Sur. Considerada como la Reina de los Mares del Sur denotaba un boato ostensible y un derroche a todo dar. Paralelamente al lento crecimiento expansivo de Lima, se consolidó el Callao, como puerto de exportación y se organizaron incipientes asentamientos residenciales al sur y oeste tales como la Magdalena, San Miguel, lugares de veraneo y recreo en Chorrillos (un ejemplo es la playa de Agua Dulce, otrora favorita de la aristocracia virreinal).

Algunos viajeros alabaron la amplitud de sus calles y plazas, su trazo recto, la amplitud de sus huertas y jardines a diferencia del trazo sinuoso de las ciudades medievales europeas ${ }^{13}$.

Al finalizar el siglo XVIII, la capital contaba con 456 hectáreas entre las que se contaban 355 calles y 3,44l casas habiéndose creado un área de recreación para la aristocracia, obra del virrey Amat (Alameda de los Descalzos, Paseo de Aguas, Coso de Acho). A este cuadro urbano debemos añadir las áreas de cultivo regadas por dos grandes canales, el de Surco y el de Magdalena. El primero recorría haciendas y chacras hasta desembocar en el mar, por lo que adquirió categoría de río. Alrededor de él se formaron los valles de Ate y Surco lindantes con Lurín. El canal de Magdalena irrigaba Magdalena, Maranga y las proximidades de Bellavista. Hacia la otra ribera del Rímac se formó el valle de Lurigancho y entre Lima y el Callao, el valle de Bocanegra, limítrofe con el valle de Carabayllo, alrededor del río Chillón.

Hacia 1791 había 32,721 plebeyos en la capital entre indios, negros, mulatos y mestizos. De ellos 2,093 eran sirvientes; 1,029 artesanos; 9,229 esclavos y habían 19,232 vagos, señal

13 Le Sieur Bachelier, "Lima en 1709". En "Pequeña antología de Lima”. Recopilado por Raúl Porras Barrenechea. Madrid 1935, Imprenta de Galo Sáez, Mesón de Paños, 6, Lima, 1965, páginas 204-205. 
de que el sistema colonial no organizaba trabajo para todos sino que era altamente excluyente. Abundaban los mercachifles o ambulantes, los que aumentaron. La plebe definió en esa sociedad altamente estratificada y estamental, a los que carecían de ocupaciones y oficios permanentes y definidos. Además de su frágil condición económica se contraponían a la aristocracia por vivir al margen de la "cultura".

La población española vivía dedicada al parasitismo de las actividades de dominación (encomenderos, labores militares); también a actividades comerciales tanto urbanas para el mercado interno como de comercio con diversos puntos del virreinato. La creación posterior de los virreinatos de Nueva Granada y de La Plata permitió el surgimiento de otras ciudades las que pudieron comerciar directamente con Europa perdiendo Lima su sitial de capital administrativa, comercial y cultural de América del Sur.

Lima llega a 1821 con unos 64,000 habitantes, unas 2,627 casas medianas y pequeñas, con $47 \mathrm{I}$ callejones y 92 corralones y solares, lo que indica un $4 \%$ de tugurización y un elevado movimiento comercial expresado en un $41 \%$ de puertas y tiendas ${ }^{14}$.

El chismorreo se daba en sus plazas, parques, calles, jirones. Ineludible el gran jirón fundacional, el Jirón de la Unión en el que se asentaron los principales solares estableciéndose en los jirones transversales las principales tiendas, las que a la usanza de los gremios de la Europa feudal se convirtieron en calles organizadas según las actividades artesanales, profesional y /o comerciales que en ellas se realizaban. Lo gremial-artesanal determinaba la organización urbana, las calles se especializaban

14 ONEC, Boletín de Análisis Demográfico: "La población del Área metropolitana de Lima-Callao", Lima julio 1975, № 15, página 10. 
en determinada actividad y en su consiguiente comercialización. Así surgieron los nombres coloniales de Espaderos (vendedores de espadas), Cuchilleros, Pescadería, Mercaderes, Mantas, Bodegones, Sombrereros, Plumereros, Botoneros, entre otros.

Esa Lima no había cambiado con la República y, por tanto, será el escenario en que vivirá Palma. El escritor, además, ha escuchado en su niñez y adolescencia y vivido en medio de los dichos de la gente y de los cronistas extranjeros de que Lima era una de las ciudades más bellas del mundo.

Ya con Cieza de León, Bernabé Cobo, Fray Reginaldo de Lizárraga, Juan de Ulloa, Radiguet, Sartiges, Angrand y otros nace la leyenda narcisista sobre Lima, aquella que cual Narciso se miraba en el espejo y caía enamorada de ella misma. Cobo llega a la capital en 1570 y hablará del vergel prehispánico, al mismo tiempo que se organizaban y segregaban los barrios pobres. El cronista Fray Reginaldo de Lizárraga que llega a Lima en 1630, ya avanzada la Colonia, compara a la capital peruana con un bosque de limoneros y Jorge Juan y Antonio de Ulloa la asemejan a un bosque ya que casi todas las casas tenían sus huertas con árboles frutales y espacios para recreo y diversión. Se crean así las bases para denominarla la Reina de los Mares del Sur, la Tres veces Coronada Villa, la Perla del Pacífico, la "Ciudad Jardín" (siguiendo al urbanista inglés Ebenezer Howard). Es la leyenda que va de "Historia de la fundación de Lima" del padre Cobo en el siglo XVII a "Una Lima que se va” de José Gálvez en el siglo XX. Muchos extranjeros la fetichizarían (franceses, ingleses, italianos, norteamericanos, españoles e hispanoamericanos, alemanes, hasta rusos $)^{15}$.

15 Testimonios reunidos por Porras Barrenechea en "Pequeña antología de Lima”, segunda edición, Lima 1965 o don Estuardo Núñez en "Relación de Viajeros, Colección Documental de la Independencia del Perú”, tomo XXVII, 4 vv., Lima $1971-1974$. 
Dice Pacheco Vélez que Lima fue defendida por Riva Agüero y por numerosos limeñistas peruanos como José Gálvez, Luis Fernán Cisneros, Héctor Velarde, Aurelio Miró Quesada, Pedro Benvenuto Murrieta, Manuel Solari, Guillermo Lohmann Villena, Juan Manuel Ugarte Eléspuru, Bruno Roselli, Víctor Pimentel y muchos otros ${ }^{16}$.

Pero, a su vez, crece la leyenda negra sobre Lima, aquella que plantea que la capital peruana es la fuente de todos los males nacionales. Destacan en esta línea de pensamiento Concolorcorvo (Cusco), Terralla y Landa de "Lima por dentro y por fuera" (fines del XVIII) hasta "Lima la horrible" (1964) de Sebastián Salazar Bondy. Javier Sologuren hablaría de "la ciudad inculpada", el poeta Jorge Eielson la compara con un cementerio, Belli la acusa de ser una ciudad-cepo que se traga a sus habitantes, Antonio Cisneros la califica de ciudad mongólica.

Palma, consciente de estas leyendas sobre la capital peruana, no se identifica con ninguna de estas posiciones extremas. No es un hombre que odia a la ciudad, la ama pero no cae en los ultraísmos endiosadores de los narcisistas como tampoco en culparla de todos los males nacionales. Es más, sus alfileterazos contra la clase dominante virreinal nos hacen ver que estuvo más bien del lado del cambio social; fue liberal, estuvo del lado del pueblo y de los independentistas.

Palma es un romántico no anclado en el pasado sino liberal en sus creencias religiosas y políticas. Fue romántico en el arte y liberal en el pensamiento y la política. Pertenece a la República y a la ideología liberal. Participa de numerosas

16 César Pacheco Vélez, "Memoria y utopía de la Vieja Lima". Universidad del Pacífico, Departamento Académico de Humanidades, Ediciones de la avispa blanca, Perú, Lima, diciembre de 1985, página 224. 
rebeliones contra el statu quo, con lo que indica que no miraba la vida limeña desde el mullido balcón limeño sino que era un hombre en el que se integraba el pensamiento, la palabra y la acción. Autenticidad la llaman.

Mariátegui nos dice que esta clase media, al acceder al poder, no tuvo la fuerza ni el aliento histórico para impulsar las grandes reformas necesarias para superar el dominio colonial. Mantuvo la mentalidad conservadora del virreinato como parte de las tradiciones del poder. Así dice el mismo Palma, que Lima siguió siendo como en el pasado colonial, solo que sin virreyes.

\section{La Lima de Palma}

La Lima de Palma es de 1833.Eran unas 400 hectáreas con nuevas construcciones como la Plaza de Toros que data de 1768 o el Paseo de Aguas (de 1773). Ya habían aparecido los primeros cafés llegando a siete en total ${ }^{17}$, expresión de una vida urbana agitada y cosmopolita, que se daba tanto en la calle como en el recinto doméstico. Lima vivía hacia afuera, hacia la calle, las plazas, los paseos.

Esta Lima en que vivió el patriarca de las letras peruanas era, en la bohemia de su tiempo, una aldehuela, como la hubiera llamado Luis Alberto Sánchez refiriéndose a la Lima de inicios del siglo XX, que retrata genialmente en sus novelas últimas "Los señores", "Los burgueses". Era una ciudad muy pequeña, aun amurallada, área de chismorreo propio de pueblos pequeños y beatas dicharacheras. Ese espíritu lo ha tomado Palma de la gente indudablemente y con su vena literaria lo ha llevado a una cumbre mayor.

17 Alberto Flores Galindo, ob. ant. cit., página 9. 
Palma nace en una Lima de unos 54,600 habitantes, cerrándose el siglo XIX con 103,956 personas.

\begin{tabular}{cccc}
\hline Años & Habitantes & Tasa de crecimiento media anual & Superficie \\
\hline 1821 & 63,315 & - & - \\
1826 & 60,000 & -1.07 & - \\
1836 & 54,600 & -0.94 & - \\
1839 & 55,627 & 0.62 & - \\
1857 & 94,195 & - & - \\
1859 & - & - & 417.12 hás. \\
1876 & 100,156 & - & - \\
1891 & 103,956 & - & - \\
\hline
\end{tabular}

El tradicionista revela una gran versación sobre los nombres coloniales de las calles, sus múltiples denominaciones, las motivaciones de esos nombres, mil y una anécdotas en las que se regodea y utiliza para darnos una visión de la Lima de su tiempo.

Tras los años de la independencia la ciudad de Lima parece haberse detenido e involucionado. Pacheco Vélez sostiene que es una "...Ciudad estancada que va tejiendo sobre la borrosa memoria de un esplendor real una nueva leyenda romántica, aldea grande, dormida bajo las "caricias de un cielo sin nubes (sic) y cuyo clima "son brisas sin lluvias y una luz tibia de eterna bonanza", como dirá Vicuña en una imagen estereotipada que hallamos también en las páginas de Max Radiguet y en la mayoría de viajeros románticos. La estampa, algo convencional, se aviva en el pincel ágil y veraz del mulato Pancho Fierro y de otros costumbristas criollos que casi sin quererlo denuncian con eficaz vena satírica los males de la sociedad republicana" ${ }^{18}$.

18 César Pacheco Vélez, ob. ant. cit, página 259. 
Lima queda paralizada durante las cinco primeras décadas del siglo XIX, por lo que se conserva prácticamente la ciudad medieval, colonial de puertas hacia adentro manteniéndose intacta la unidad y armonía de la vieja ciudad virreinal intramuros: sus balcones de cajón, la paz y unidad de las viejas casas con sus zaguanes y sus patios rumorosos.

Con Ramón Castilla empieza un renacimiento. Llega el alumbrado con gas, los ferrocarriles, las verjas de fierro que bordean los atrios de las iglesias; se embellece la Alameda de los Descalzos.

Es en estos años que Ricardo Palma crea esa especie literaria que es la tradición, a través de las cuales hace desfilar a incas, reyezuelos, conquistadores, damas, clérigos, tapadas, gente del común. Con vena democrática trata y caricaturiza principalmente a la nobleza virreinal y a toda su parafernalia, destacando las imágenes del siglo XVIII. Prefiere los palacios, los conventos, las callejuelas oscuras de la Lima de aquel entonces. Su carácter juguetón, retozón y burlón derrama su sátira sobre todo contra los nobles, los funcionarios coloniales y el clero, los que recibieron las mejores puyas de su punzante ironía.

Nos refiere Jorge Basadre en "La multitud, la ciudad y el campo en la historia del Perú" que "No es extraño que, acaso con significado único en América, abundaran en Lima entonces quienes sentían la nostalgia de los días coloniales. En ellos había habido más alegría, más felicidad, más tranquilidad, más boato. La capital conservó, sin embargo, su ambiente original, hasta 1850 más o menos, seduciendo incesantemente a los viajeros. Las mujeres mantuvieron hasta mediados de siglo su vestido típico, variando solo sus características menores: colores según la estación y según el caudillo de moda, saya estrecha o saya desplegada. En la saya y manto está la 
expresión del estatismo social de aquella vida porque esa perduración va contra la mudabilidad que por antonomasia caracteriza a la moda y está la expresión también de una ciudad en que impera el espíritu de predominio femenino, de clandestinidad, de chismorreo... No es solo escénicamente el personaje principal, en la plaza mayor, en los portales, en las iglesias, en el Puente, en Acho y en el teatro...Pero no es la mujer lo único que alegró aquella vida, a pesar de que los nostálgicos de la colonia la veían en plena decadencia. Lima conservaba su ambiente de fiesta, amaba las corridas de toros de Acho...que entraron en competencia con la ópera italiana cuando entre 1840 y 1844 , se difundió el gusto por ella, las funciones de ópera y de drama primero, de zarzuela y ópera... Las jugadas de gallos, los nacimientos de Navidad, los títeres y volatines, los fuegos artificiales, las procesiones más importantes eran las de Santa Rosa... y la de Corpus Christi... Los carnavales se jugaban con frenesí, rompiéndose con ese pretexto una serie de frenos sociales y cayéndose en lo licencioso... Los paseos a Amancaes... Pero al mismo tiempo primaba un espíritu cerrado y pequeño. El estatismo social da lugar a los dos tipos más pintorescos que exhibe la literatura de entonces: $\mathrm{Na}$ Catita, la beata chismosa y el niño Goyito que pintó Pardo en quien se encarna el conservadorismo, el retardismo, el limeñismo enemigo del viaje y del intercambio, la candidez engreída y mimada que hay en las clases altas limeñas. Cuando la imaginación evoca aquella época, se detiene en los portales o en el puente, ellos son para Lima el centro de reunión que después se desplazó al Jirón de la Unión y al Paseo Colón. Y allí en los portales o en el puente está también otro tipo fundamental de Lima de entonces: el indefinido, el estratega de corrillo, el crítico omnisapiente del Gobierno, el que inventa o propala las bolas...los pregoneros...Y también el gallinazo que realiza las funciones higiénicas...Lo típico de Lima, podría sintetizarse entonces: tapada-niño Goyito-Ña Catita-Indefinido-Pregonero-Gallinazo". 
Vemos pues que esta Lima de Palma no ha cambiado sustancialmente en lo social, en lo mental. Solo ha dejado de aparecer el virrey pero subsisten los tributos, los esclavos, las procesiones, las corridas de toros, las acequias malolientes y los gallinazos, las tapadas y las calesas.

Sus personajes son los de una Lima festiva y a la vez muda, extrovertida e introvertida. Su inmadurez es la del niño Goyito, que coincide con la aseveración de Luis Alberto Sánchez quien califica a la ciudad como "adolescente" o la del alemán Von Humboldt o Raimondi que sostienen que esta ciudad vive alejada de las provincias, negligente y sin considerar seriamente los problemas del país. Eternamente inmadura como el niño Goyito y eternamente feudal como la chismosa $\tilde{N}$ a Catita con sus gallinazos volando sobre sus cabezas y los pregoneros que anuncian tamales, fritanguita, la rica fruta y cuanta especie se pudiera comprar en la dinámica urbana de la ciudad.

Pero, como tesis central de esta ponencia, debo decir que el tradicionista se sobrepone a la cerrazón de esta pequeña ciudad, de su espíritu medieval, y lejos de ser ganado por el espíritu virreinal que impregna a la naciente república, se define como republicano, liberal y con una actitud militante ante la existencia.

Lima de entonces tenía su plaza central, su Jirón de La Unión, calles salpicadas de acequias y malas condiciones de higiene; los gallinazos sobrevolando a los animales muertos, vivanderas en plena Plaza de armas, lecheros y panaderos a caballo. Casas con huertas, trazos arquitectónicos moros, balcones, balaustres, celosías, azulejos, amplias fachadas de dos pisos en quincha y madera; calles de tierra o empedradas por donde circulaba la gente y los caballos así como los carruajes y las calesas. La Plaza de Armas seguía siendo el escenario más importante de la capital. 
La población de Lima hacia 1836 representaba solo el 4\% del total nacional (1'373,736 habs.). Aún Lima no era la cabeza poblacional del país.

Hacia 1842 Lima tenía 53,000 habitantes siendo la mayoría $(21,000)$ un conglomerado de extranjeros, mulatos y mestizos; en segundo lugar figuraban los criollos blancos $(17,0000)$; en tercer lugar los negros $(10,000)$ y en cuarto lugar los indios $(5,000)$. En su mayoría, los mestizos, indios y algunos extranjeros se dedicaban al pequeño comercio; las actividades financieras y el gran comercio eran controlados sobre todo por los ingleses. El sector criollo tenía en sus manos el aparato político-administrativo y en menor medida los mestizos. En los referente a lo urbano, Lima tenía unas 3,380 casas, 34 plazas públicas delante de las iglesias y 419 calles, la mayoría mal pavimentadas si bien tenían veredas. Las murallas estaban muy deterioradas hacia $1840^{19}$.

Los años de la anarquía militar expresaron la inexistencia de una clase social que comandara el proceso de unificación nacional tras la independencia. Faltaba una clase social con un proyecto nacional que uniera a todo el país.

Sostiene José Carlos Mariátegui que "La revolución encontró al Perú retrasado en la formación de su burguesía. Los elementos de una economía capitalista eran en nuestro país más embrionarios que en otros países de América donde la revolución contó con una burguesía menos larvada, menos incipiente. Si la revolución hubiese sido un movimiento de las masas indígenas o hubiese representado sus reivindicaciones, habría tenido necesariamente una fisonomía agrarista...Pero, para que la revolución demo-liberal haya tenido estos efectos, dos premisas han sido necesarias: la existencia de una burguesía consciente

19 J.J. Von Tschudi, “Testimonio del Perú 1838-1842”, página 80. 
de los fines e intereses de su acción y la existencia de un estado de ánimo revolucionario en la clase campesina y, sobre todo, su reivindicación del derecho a la tierra en términos incompatibles con el poder de la aristocracia terrateniente. En el Perú, menos todavía que en otros países de América, la revolución de la independencia no respondía a estas premisas. La revolución había triunfado por la obligada solidaridad continental de los pueblos que se rebelaban contra el dominio de España y porque las circunstancias políticas y económicas del mundo trabajaban a su favor. El nacionalismo continental de los revolucionarios hispanoamericanos se juntaba a esa mancomunidad forzosa de sus destinos, para nivelar a los pueblos más avanzados en su marcha al capitalismo con los más retrasados en la misma vía... La aristocracia terrateniente, si no sus privilegios de principio, conservaba sus posiciones de hecho. Seguía siendo en el Perú la clase dominante. La revolución no había realmente elevado al poder a una nueva clase. La burguesía profesional y comerciante era muy débil para gobernar. La abolición de la servidumbre no pasaba, por esto, de ser una declaración teórica. Porque la revolución no había tocado el latifundio. Y la servidumbre no es sino una de las caras de la feudalidad, pero no la feudalidad misma..." 20 .

Era de suponer que esa clase media criolla adviniese en burguesía que lanzara un proyecto nacional de desarrollo, entusiasmara al conjunto de clases sociales en el territorio nacional y lanzara un cambio radical. Pero no solo no existía sino que lo que había era muy débil. Eran pensadores, filósofos, intelectuales pero no estaban ligados a la tarea productiva. No teníamos una burguesía y eso llevó a que, liberados del dominio español, pasáramos a los años de anarquía militar ante la falta de una

20 José Carlos Mariátegui, 7 ensayos de interpretación de la realidad peruana, Biblioteca Amauta, Lima-Perú, Vigésima sexta edición y duodécima popular de abril de 1973, página 66. 
clase conductora del país. El propio caudillaje militar, varios presidentes al mismo tiempo que decían gobernar en nombre del país, era producto natural de un período revolucionario que no había podido crear una nueva clase dirigente. Carecíamos de una clase burguesa capaz de organizar un Estado fuerte y apto. Por eso, en esos años de anarquía, el militarismo representaba un orden elemental y provisorio. Con Castilla fue con quien el militarismo avanzó más, medido esto en la abolición de la esclavitud de los negros y de la contribución de indígenas. Ese fue su máximo aporte liberal.

Castilla representa el primer esfuerzo centralizador contra la anarquía militar. Nada menos que un militar combate la anarquía militar. El boom guanero dio un respiro a las arcas fiscales y permitió combatir a los ejércitos de los caciques regionales. La capital se moderniza siguiendo los cánones de la estética helena, tan caros a la clase gobernante. A su vez se dan los primeros intentos de centralización política del país. El enriquecimiento fiscal tras el boom guanero permitió a Castilla intentar la modernización del país y su capital. Une Lima al puerto del Callao a través de un ferrocarril, adquiere los servicios de agua de los que carecía hasta entonces e impulsa el enlosado y alumbrado de las calles. Repara la Alameda de los Descalzos y erige los monumentos a Colón y Bolívar. Con Castilla encuentra Lima el espíritu de remozamiento urbano expresado en construcciones, tales como el Mercado Central (1846-1855) y el Hospicio Ruiz Dávila. Favorece el fausto de las clases adineradas, surgiendo las grandes mansiones republicanas mientras en lo socio-étnico se hunde lo regional empezando a primar lo cosmopolita. Eran tiempos en que el capitalismo no era la estructura predominante en el país. Primaban los arquetipos feudales, el vasallaje servil en el campo y el carácter de gran señor del patrón. Lima era una aldehuela a cuyo centro tradicional se añadía Abajo el Puente 
y los Barrios Altos. La tradición de "ir al centro", "Jironear", tan caras al criollo limeño, eran cosas de todos los días dada la escasa dimensión de la capital.

Entre 1847 y 1851 se crearon numerosas fábricas (textiles, vidrios, papeleras). Hacia 1857 Lima tenía diversos indicadores de modernidad (alumbrado de gas, telégrafo, teléfono, ferrocarril Lima-Callao-Lima y Lima-Chorrillos). Ya el avance urbano tocaba las murallas y se sentían los primeros síntomas de estrechez urbana.

Mientras la burguesía se organizaba, el poder estuvo a manos de los caudillos militares. Con Castilla se solidifica una clase burguesa, a partir del boom guanero, de las ganancias que les diera ir en unión con la burguesía inglesa que llegaba a estos predios a llevarse el fertilizante.

En ese contexto es que Palma y su obra expresaron al espíritu criollo y a la mesocracia de una Lima republicana que ante la ausencia de una burguesía revolucionaria e incapaz de convertirse en tal clase, resolvió su conflicto y su rebeldía en alguna asonada y centralmente en el chisme y la murmuración. Fue el modo como dieron salida a su inquietud republicana, en un mundo en que la aristocracia virreinal pretendía retomar las riendas del Estado tras las guerras independentistas, a falta de una burguesía que planteara una imagen de modernidad para el conjunto de la sociedad peruana. Frente a la ideología urbana impuesta por la aristocracia, Palma escribe precisamente para hacerla leña. De este modo traduce al criollismo, el mestizaje, la mesocracia de una Lima republicana a la que una serie de circunstancias históricas frustró su devenir en burguesía, si bien se mantuvo adversa a la vieja aristocracia.

Lo dicho no niega en ningún momento que el tradicionista haya desdeñado la Lima popular o la dimensión popular de 
esta. De hecho se podría decir que toda la perspectiva de la obra de Palma está identificada con la gente del pueblo de la ciudad, del populacho ubicado Abajo el puente, mientras que la Lima aristocrática estaba por encima del nivel del río Rímac ${ }^{21}$.Palma interpreta a los de abajo, al medio pelo, burlándose del prestigio del virreinato y de la aristocracia. El suyo es el descontento zumbón del demos criollo, cuya rebeldía se resolvía en el chiste, el chisme, la murmuración.

Su obra refleja en todo caso la estrecha interrelación de ambas Limas, la señorial y la popular, las que tampoco estuvieron divorciadas y separadas. Justamente el mundo de los ambulantes coloniales y posteriormente republicanos nos ilustrará esta interrelación. En la tradición "Con días y ollas venceremos", Palma presenta justamente el caso de los habitantes de la Lima pobre pasando a la Lima señorial a vender sus productos. Estos vendedores con sus pregones prácticamente daban la hora de antaño en una Lima sin relojes. Esta tradición ha sido musicalizada por Alicia Maguiña en el vals criollo "Viva el Perú y sereno"22.

Son personajes propios de la colonia y que sobrevivieron tras las guerras independentistas, típicos en las estampas de Pancho Fierro, los que le daban una atractiva fisonomía a la ciudad. Algunos de ellos, como el humitero, el tamalero, las anticucheras, el vendedor de "revolución caliente" y otros, mantienen aún hoy el pasado feudal de Lima.

Desde las seis de la mañana iban desfilando por la Lima señorial estas figuras populares. La lechera, la chichera, la tisanera, el panadero a mula, la vendedora de leche-vinagre, los aguadores,

21 José Carlos Mariátegui, "Ricardo Palma, Lima y la Colonia”. En "Siete ensayos de interpretación de la realidad peruana”, edición ant. cit., páginas 244-250.

22 Ricardo Palma, “Con días y ollas venceremos". En las Tradiciones Peruanas Completas, ob. ant. cit, páginas 956-962. 
el zanguito de ñajú, el que vendía choncholíes, las vendedoras de pescado fresco, la melonera, el del ranfañote, los frijoles colados y zalamerías, el frutero, los vendedores de ante, la arrocera y el alfajorero, el humitero, la picaronera y el hombre de la rica causa de Trujillo, los vendedores de aves, el melcochero, la turronera y la anticuchera, la picantera, el de la piñita de nuez, el canastero, el botijero de vinos de Pisco, el jazminero; el vendedor de queso fresco, el mantequero, el raicero y el galletero. A las siete una mujer traía mazamorra morada coincidiendo con el caramelero, el champucero, los helados de piña y de leche. A las nueve un pregón que aún hoy suena en Lima, como que se ha quedado en la máquina del tiempo cantado por un personaje de saco, morral y linterna en pleno día o noche: «iRevolución caliente, para rechinar los dientes!» A las diez de la noche, el sereno del barrio, policía de aquel entonces, cantaba cada sesenta minutos entre pitazo y punteo: iAve María Purísima! Las diez han dado. iViva el Perú y sereno!

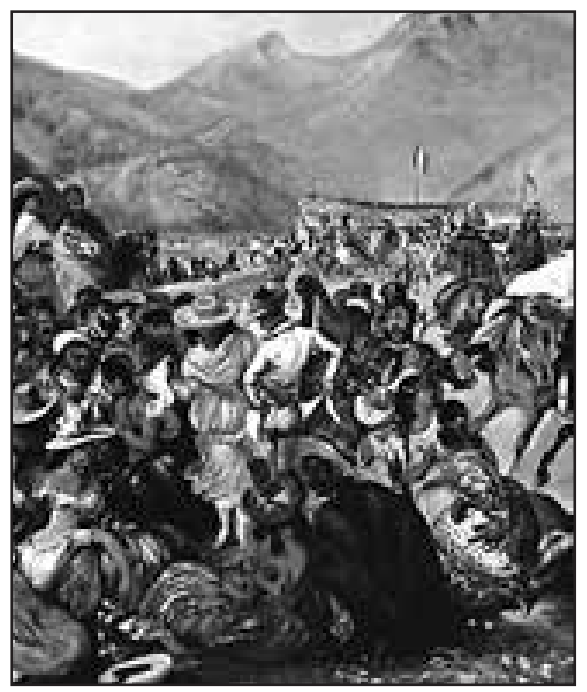

Características sociourbanas de la Lima de Ricardo Palma. 
Este es el paisaje en que crece Palma, un ambiente feudal, propio de aquellas sobre las que se dice «ciudad pequeña, infierno grande». Él, siempre curioso desde niño y extrovertido, ingresa en este mundillo y coge lo mejor de la vena criolla limeña, la sátira; la exhibe, la extravierte en sus escritos. Lo hace recuperando el habla popular, como consta en sus tradiciones, las costumbres del pueblo, sus dichos y zalamerías.

Lima era una aldehuela feudal que iba entre cierra puertas y tremendas montoneras. El Perú y su capital iban a la deriva.

Dice Pacheco Vélez ${ }^{23}$ que entre mediados del siglo XIX y el primer tercio del siglo XX, entre los gobiernos de Ramón Castilla y Leguía, Lima pasa de 70,000 a 300,000 habitantes.

Una segunda etapa de remozamiento urbana de Lima se dará con Balta (1868-1872) y la continuación de su entusiasmo constructor hasta la crisis de 1879. La obra decisiva será la demolición de las murallas de Lima, que atenazaban a una ciudad que pugnaba por ingresar al mercado abierto del capitalismo y al que las murallas servían como corset paralizador. Se siguió la moda iniciada en París, en Roma y en otras ciudades del viejo mundo y a la cual se había adelantado La Habana casi por dos lustros (1853).

Durante el gobierno de Balta se derrumban las murallas bajo la mano mercantil de Meiggs, quien lo hizo a cambio de una concesión de terrenos en donde planeó la construcción de grandes bulevares adornados por árboles entre Lima y Callao y Lima-Chorrillos. Se inicia la especulación de terrenos nuevos, expresando el nacimiento de una burguesía inmobiliaria, si bien el proyecto fracasó al no comprar nadie

23 Pacheco Vélez, ídem, página 244. 
los terrenos afectados ${ }^{24}$. Henry Meiggs es el constructor que modernizará Lima y la expandirá más allá de las murallas. Claro que el interés del ingeniero inmobiliario era acaparar tierras ricas y grandes para enriquecerse pero su mérito será el ensanchamiento de la ciudad, el que será articulado por las labores urbanísticas y planteamientos urbanos de Luis Sadá, de Manuel Ignacio Fuentes y otros.

Ya en Europa estaban de moda los aportes de Haussmann, el gran renovador de París y surgirá la ciudad de Milyutin, la ciudad lameliforme de Walter Gropius, la ciudad jardín de Ebenezer Howard, todos interesados en lograr integrar y perfilar la ciudad y el campo, la unidad agro-urbana en situaciones diferentes en cada país. Surgen mil y un modelos urbanos.

La no compra de terrenos significará la primacía del espíritu conservador al no arriesgar la compra de tierras vírgenes allende las murallas, recientemente demolidas. Sin embargo, ya el capital mercantil esperaba que llegara su hora. Jugaba además con el viento a favor al estar aliado al gobierno. Demolidas las murallas se inauguraron las avenidas Grau y Alfonso Ugarte. Desde entonces hasta ahora, el crecimiento urbano de Lima cayó en manos de especuladores de la tierra urbana.

Así Lima crece y Haussmann está presente en esa Lima de las plazas Castilla, 2 de Mayo, Bolognesi, Grau. Es la teoría del anillo de circunvalación con sus plazas circulares de las que debe salir repitiendo el esquema de La Estrella, diversas y grandes vías radiales hacia el sur, el este y el oeste.

Por entonces surgirán diversos edificaciones que representarán a esta Lima republicana como la Escuela de Artes y Oficios, la

24 Jorge Basadre, Historia de la República del Perú, Tomo IV. Quinta edición, 1961, página 1822. 
Facultad de Medicina, la Escuela de Ingenieros, la Estación de Desamparados y, años después, aparecerá el Palacio de Justicia remodelándose el viejo y construyéndose el nuevo teatro.

Balta encargó al ingeniero Luis Sadá elaborar una propuesta de desarrollo urbano. Además, construyó la carretera entre Lima y Callao, inauguró el puente nuevo sobre el río Rímac y el Barrio de La Victoria, el primero en expandirse al no encontrar la resistencia que otrora habían sido las murallas. Hacia 1872 se construyó el Palacio de la Exposición, límite de la ciudad que se mantendría hasta la segunda década del siglo XX como una frontera urbanizada. En este Palacio, la gente adinerada paseaba, asistía a conciertos y actividades sociales.

Hacia 1870 se instalaron las primeras fábricas, los primeros telégrafos, paseos y parques, iluminación, etc.

Lima, ya sin murallas, inició su expansión. La Victoria fue el primer avance de consideración incorporando una nueva área urbana de 747,318 m2 de los que 268,514 m2 correspondían a la superficie libre. Se consolidó el crecimiento hacia el este (Barrios altos) mientras la burguesía mercantil y exportadora se localizaba en Miraflores, Barranco y Chorrillos, San Miguel y Magdalena.

La imagen de Lima como una ciudad de leyenda, de los viejos recuerdos ha sido pintada por Marcel Monnier en los años inmediatos a la Guerra del Pacífico. Su descripción alimentará la imagen de una ciudad que vive bajo el manto de una extraviada nostalgia, que respira el pasado por todos sus poros, que tiene la bruma de los tiempos idos, el sabor del recuerdo. Lima posee"...lo que le falta a la mayoría de sus florecientes rivales, en particular a las aglomeraciones norteamericanas: la poesía de los viejos recuerdos... La casa revela al que la habita. La adivinareis detrás de las celosías cerradas...Es la limeña: 
marcha ondulante, grandes ojos negros...piedad ferviente, gracia mundana" 25 .

La derrota militar frente a Chile cortó el crecimiento de Lima, sucediéndose posteriormente largos años de reconstrucción. Entre 1895 a 1919 se dio el apogeo de la oligarquía, período que Basadre denominará República Aristocrática. Se trataba de la dominación de un conjunto de familias que controlaban las arterias vitales de nuestra sociedad. La oligarquía se sustentaba en el respaldo que podía recibir del imperialismo y en la violencia que la alianza caciques latifundistas (gamonales) y la gran burguesía (señorones del azúcar, arroz, algodón) ejercían sobre el país. Así, entre 1899 y 1912 se sucedieron en el poder gobiernos representativos de la oligarquía civilista: López de Romaña, Candamo, José Pardo y A.B. Leguía. Nuestra sociedad seguía siendo centralmente agraria primando en la clase dominante la visión de que el Perú está constituido y dividido entre blancos y nativos. Se reprodujo la concepción virreinal que dicotomizaba al país entre una república de españoles y una república de indios.

La Guerra del Pacífico traerá ruina a la ciudad. La Biblioteca de Lima será quemada y su reconstrucción será la gesta central de Ricardo Palma.

"Luego del paréntesis producido por la crisis fiscal y la guerra, se inició con Piérola en 1895 una nueva época. El trazado del Paseo Colón y la av. Brasil marcaron el rumbo de la ciudad hacia la zona costeña del sur con la apertura de urbanizaciones... Surgen nuevos edificios como la Casa de Correos y el Mercado de Guadalupe reflejando el impulso urbanista. Como ha observado José Gálvez en “1895”, bella crónica inserta en el libro Una

25 Marcel Monnier, “Lima después de la Guerra de 1879”. En Pequeña antología de Lima, 1965, páginas 307-308. 
Lima que se va, documento esencial para el estudio de esta época, lo edilicio o arquitectural tuvo menos importancia que la transformación en las costumbres y el espíritu. Comenzaron a esfumarse la vida y la mentalidad aldeanas" 26 .

La construcción del Palacio de la Exposición y del Paseo Colón y la avenida La Colmena (durante el gobierno de Piérola 18951899) iniciaron la era de estilos afrancesados.

Esto último coincide con los últimos años de Palma tras su retiro de la Biblioteca Nacional, su pase al cuartel del descanso en Chorrillos y Miraflores. Lima crece, deja de ser una aldea y sorprende a Palma ya mayor, en sus últimos años.

\section{Desarrollo urbano de Lima en el siglo XX}

Alboreando el siglo XX, Lima contaba con unos 120,000 habitantes, la mayoría de los cuales vivía en el Centro y sus áreas aledañas, mientras que otro sector social estaba diseminado en diversos distritos separados por chacras, huertos y haciendas. Pasa a ser una ciudad de 200,000 habitantes en 1920 y así sucesivamente.

Aquí intento armar un cuadro juntando información del Censo de 1876 con el de 1908 y datos posteriores.

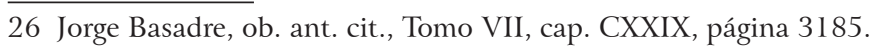




\begin{tabular}{llllll}
\hline \multicolumn{1}{c}{ Años } & No Hab. & Hás. & Hab/há. \% & $\begin{array}{c}\text { Crec. último } \\
\text { censo }\end{array}$ & $\begin{array}{c}\text { Aumento de } \\
\text { Hab. }\end{array}$ \\
\hline Censo 1876 & 100,156 & & & & \\
$1903-1904$ & 130,289 & & & & \\
Censo 1908 & 154,624 & 1,292 & 153 hab/ha & $54.3 \%$ & 54,428 \\
1920 & 198,875 & & & $28.6 \%$ & 44,223 \\
1931 & 334,159 & 2,037 & 134 hab/ha & $68.0 \%$ & 135,236 \\
1940 & 520,000 & & & & \\
1961 & 1 1'850,000 & & & & \\
\hline
\end{tabular}

Hacia 1907, la avenida La Colmena avanzaba incontenible, pese a la resistencia de los intereses mercantiles y de algunos propietarios. La Plaza Bolognesi y el Paseo Colón o 9 de Diciembre eran los paseos de moda, símbolos de lujo, de modernidad. Tras la demolición de las murallas, el Barrio de La Victoria había dejado sentir su presencia en la ciudad y se estaba edificando el barrio de Cocharcas con mejores viviendas para el peón y el artesano.

Steve Stein nos dice que a inicios del siglo XX: "Lima era todavía una serie de barrios algo independientes, con sabor colonial. Tal era la falta de integración de Lima como ciudad que sus habitantes se identificaban más que como limeños: de acuerdo a su barrio o su calle eran bajopontinos, o de Maravillas, o de la Calle de la Cruz..."27.

En pocos minutos el habitante de la ciudad podía recorrer la parte central de la ciudad, desde la Plaza de Armas hasta el Paseo Colón. La campiña de Lima de unos 300 kilómetros cuadrados, era propiedad de unas 296 personas.

27 Steve Stein, Lima obrera 1900-1930. Tomo I, Ediciones El Virrey, edición primera, Lima febrero de 1986, página 13. 
No era una vasta área la dedicada a las tareas agrícolas. Viajar de Lima a Chorrillos en tren llevaba a cruzar estos campos de cultivo, sea de pan llevar, de algodón o sencillamente matorrales.

La desintegración de Lima centro, con sus extremos (Miraflores, Barranco, Chorrillos), fue superada por la labor unificadora de Leguía (1919-1930). El mito de "Ciudad Jardín" estaba en marcha alimentado por las propias clases gobernantes. Paralelamente surgían barrios obreros y zonas altamente tugurizadas (El Barrio Chino, Capón y el perímetro de la avenida Abancay hasta la Plaza Italia, a los que de acuerdo al censo de 1903 habría que añadir 67 l callejones. Ya para entonces en la huerta de La Victoria había surgido un barrio obrero y hacia el Este la pequeña burguesía improvisaba el barrio alegre del Chirimoyo.

Hacia 1920 Lima tenía unos 200,000 habitantes y empezaba la industrialización urbana, dándose una fuerte migración provinciana hacia Lima. El crecimiento demográfico generó una revaloración de la propiedad urbana beneficiándose los dueños de tierras hacia las cuales se extendía la ciudad. Lima tenía 1,136 hectáreas de las cuales 1,020 pertenecían a la parte urbana; habían 18,776 casas. La inauguración de la Plaza San Martín en 1921 dio paso a una nueva arquitectura construyéndose edificaciones de más de seis pisos. El afrancesamiento de la Plaza Dos de Mayo, lo británico del Country Club, Golf Club y el Hipódromo de Santa Beatriz reflejaron el gusto europeizante de la clase dominante, pese al ingreso a raudales de los capitales norteamericanos durante el Oncenio de Leguía.

Con Leguía llega la tercera modernización. Se expande la ciudad hacia el sur, hacia el mar con la avenida Leguía o Arequipa así como las avenidas La Paz, Progreso o Venezuela, la Colonial. Lima se articula a todos sus extremos y crece. 
Palma muere en 1919, es decir, justo antes de iniciarse los 11 años de gobierno de Leguía. Será luego entre 1940 y fines del siglo XX, que la capital peruana pasará de 400,000 habitantes a unos 6 millones. Hoy se aproxima amenazadoramente a diez millones conformando lo que se denomina una moderna megalópolis.

Lima era una tranquila aldea por estaciones y revoltosa en otros momentos; se desperezaba cada cierto tiempo, bostezaba y entonces se tenía una revolución.

Palma tiene una versación sobre la historia nacional, conseguida a lo largo de su vida y su episodio como bibliotecario mendigo tras la Guerra del Pacífico le debe haber dejado grandes nostalgias de esta ciudad capital. Ha leído mucho sobre ella y conoce los intríngulis de la ciudad capital. Recoge el humor popular, dicharachero, el chismorreo, del cotilleo por lo bajo, y lo hizo objeto de burla del sistema imperante por entonces. Crea en mucho esa "alma ciudadana" de la que nos habla Spengler. Tal vez allí podamos entender ese aserto de Porras Barrenechea de que "Lima...la fundaron en colaboración don Francisco Pizarro y don Ricardo Palma"28. El europeo fue el que colocó la primera piedra pero el que la pobló de imágenes fue indudablemente su tradicionista, que no tradicionalista, los que suelen vivir anclados en el pasado. Roberto Reyes se pregunta: “iSe trata quizás de que Palma está fundando con sus Tradiciones una topografía física y espiritual de la nueva ciudad que va emergiendo del pasado, como lo hizo Balzac con París en "La Comedia Humana", Moravia con Roma en sus "Cuentos romanos", o Dos Passos con Nueva York en "Manhattan Transfer"?...La respuesta a esta última pregunta es sí y no. Sí, porque es mediante la ficción narrativa que Palma

28 Raúl Porras Barrenechea, "Presentación y autocensura" de "Pequeña Antología de Lima” (1535-1935), página 9. 
crea la Lima de la que tantos lectores, antes y ahora, se sienten fascinados. No, porque la Lima que crea Palma es la del pasado, principalmente la del siglo anterior al suyo...Lo que hizo fue crear una monumental obra de ficción que dio un extraordinario significado a la vida de sus antepasados; fue construir una Lima imaginaria, pero con más influencia en la vida real que la de cualquier político, comunicador o administrador de la ciudad; fue dar a los limeños una identidad, articulando una conciencia colectiva que subsistía al cabo de casi un siglo; pero sobre todo, lo principal que hizo fue crear un conjunto de historias y personajes que aún nos hacen sonreír y emocionarnos y hacernos soñar despiertos" 29 .

Hay en todo lo dicho mucho de esa alma ciudadana spengleriana, quien sostiene que "El verdadero milagro es cuando nace el alma de la ciudad. Súbitamente, sobre la espiritualidad general de la cultura, se destaca el alma de la ciudad como un alma colectiva de nueva especie...Y este conjunto vive, respira, crece, adquiere un rostro peculiar y una forma e historia internas. A partir de este momento, además de la casa particular, del templo, de la catedral y del palacio, constituye la imagen urbana en su unidad el objeto de un idioma de formas y de una historia estilística, que acompaña en su curso todo el ciclo vital de una cultura" 30 .

No toda ciudad es igual por ello. Podemos estar en Santiago de Chile, en Buenos Aires, en Río de Janeiro y de inmediato captamos su elan urbano, su elan ciudadano, ese espíritu que rezuma toda ciudad a partir de la línea de sus calles, de

29 Roberto Reyes Tarazona, "La Lima de Ricardo Palma”. Discurso leído el 20 de agosto de 1998 en ceremonia de incorporación al Instituto Ricardo Palma de la Universidad Ricardo Palma. Revista Aula Palma, "Discursos de incorporación 1998-1999”, primera edición, Lima-Perú, octubre de 1999.

30 Oswald Spengler, "La decadencia de Occidente", Calpe, Madrid 1926, Volumen III, página 131 de la traducción del alemán al español por Manuel G. Morente. Segunda Parte, "Perspectivas de la Historia Universal". 
sus recovecos, de la traza de sus habitantes, de la limpieza o suciedad de sus calles, del orden de sus veredas, de la cara de sus habitantes, de su amabilidad o cortedad. Ese elan ciudadano es muy común a cada ciudad y por ello cada una nos impresiona de modo permanente. Hay tanto parecido entre ciudades italianas y Buenos Aires, como el orden de Santiago de Chile impresiona y el desorden de Lima impresiona a su vez.

En fin, qué duda cabe, don Ricardo Palma ha creado en mucho las imágenes que pueblan nuestras mentes y se ha convertido en el escritor que orienta nuestras aspiraciones, nuestra identidad, nuestro apego a la ciudad. 